\title{
Commitment or Compliance? Institutional Logics of Work Environment Management ${ }^{1}$
}

I Christian Uhrenholdt Madsen ${ }^{2}$

PhD Fellow, Center for Industrial Production, Aalborg University, Denmark

I Peter Hasle

Professor, Center for Industrial Production, Aalborg University, Denmark

\begin{abstract}
Scholars of the work environment have pointed out how management ideas and practices inspired by a human resource approach are influencing the work environment efforts in Nordic organizations. In this paper, we use the 'institutional logics' perspective to propose heuristic ideal types of two institutional logics of work environment management: The logic of compliance as the ideal type of the 'traditional' approach to work environment management and the logic of commitment as the human resource informed approach. Through a side-by-side comparison of key characteristics, we analyze the two ideal types as instantiations of institutional orders on the societal level with the compliance logic being rooted in the orders of the state and the corporation, and the commitment logic as based on the orders of the corporation. The paper ends with a discussion on the how the two logics can influence concrete work environment practices and approaches to management in organizations.
\end{abstract}

\section{KEY WORDS}

Commitment / Compliance / HRM / Human resource management / Ideal types / Institutional logics / Institutional theory / Occupational Health and Safety / OHS / Work environment

\section{Introduction}

he organizational approaches to work environment management are undergoing considerable change in the Nordic countries in these years, which in turn have an impact on how organizations in Scandinavia develop their strategies, systems, and practices aimed at this issue. There are three major trends behind this development: 1) The movement of governmental regulation from command-control toward increased self-regulation in the last decades (Aalders \& Wilthagen, 1997); 2) A growing social pressure on organizations to behave in a socially responsible manner (Dyreborg, 2011; Hart, 2009); 3) The still greater focus on psychosocial factors at work (Abrahamsson $\&$ Johansson, 2013). One important consequence of these changes is that organizations tend to change their fundamental approach to the work environment from an issue they deal with in order to satisfy external regulatory bodies or satisfy employee demands, toward considering the work environment as an issue in its own right which has to be

\footnotetext{
${ }^{1}$ You can find this text and its doi at https://tidsskrift.dk/njwls/index.

${ }^{2}$ Christian Uhrenholdt Madsen, Aalborg University, AC Meyers Vænge 15, 2450 Copenhagen SV, Denmark, E-mail: cum[a]business.aau.dk
} 
managed in order to secure a sustainable business practice and organizational outcomes. There is, therefore, a trend toward mainstreaming of the work environment (Pawlowska \& Eeckelaert, 2010) with the consequence that it is managed in the organizations like any other organizational issue such as recruiting, accounting, and quality control (Hasle et al., 2016).

As the work environment has to do with employees' health, it has a lot in common with human resource management (HRM), which deals with the employees. The rise of HRM is widely seen as an organizational response to the shift toward a knowledge and service-based production, and thus to a view of employees as valuable resources in the global competition (Holt Larsen, 2014). HRM has been expanding its field of attention from merely administration of personnel matters such as salary systems and competence development to a broader approach to well-being and psychosocial work environment issues. The reason is both due to concerns for social sustainability (Dyreborg, 2011; Ehnert, 2009) and the recognition of psychosocial work environment and well-being as crucial preconditions for employee commitment and engagement, and by extension better performance (Tzafrir et al., 2015). In the English-speaking world, the related concept of occupational health and safety (OHS) is already a component of HRM (Zanko \& Dawson, 2012, p. 329), which is reflected in the fact that a chapter on OHS is a standard in books on HRM for students and practitioners (see examples in Bratton \& Gold, 2012; Torrington et al., 2008).

Meanwhile, scholars of the Nordic working life studies have described how ideas and concepts from HRM increasingly have found their way into work environment management.

What we observe is that problems regarding health at work that are considered important in modern working life are increasingly managed in the human resources (HR) rather than the OSH domain. (Kamp, 2009:86)

It is furthermore suggested as an 'HR-fication' of the work environment (Kamp \& Nielsen, 2013), while other scholars also point to the same development (Abrahamsson \& Johansson, 2013; Georg, 2014; Holt Larsen, 2014; Jacobsen et al., 2013; Knudsen et al., 2011).

The consequence is an ongoing integration of the two fields of work environment and HRM. This development constitutes a challenge for the previous approach to the work environment, which up until now has been focused mainly on the management of risks and compliance to external regulatory pressures. The HRM approach may, for instance, change the focus from control of risk to the individual employee's resilience, coping strategies, and a personal responsibility for staying fit. It can therefore act as a complementary perspective that can cover crucial work environment issues in the modern working life, that a 'traditional' risk-based approach might overlook (e.g., psychosocial work environment and personal health issues). But it can, on the other hand, possibly obfuscate other and more traditional industrial risks such as accidents, chemical exposure, or repetitive strain injuries.

However, the extent of this development and the consequences for the work environment efforts remains up to now under-researched (Zanko \& Dawson, 2012). One challenge for this endeavor is that the key constructs-'work environment', 'occupational health and safety', and 'human resource management'-have a multitude of different meanings and 
a lack of clear consensus about definitions. It is therefore necessary to conceptualize these constructs and thereby create a foundation for future theoretical discussions and empirical studies. To do this, we build on institutional theory-specifically the institutional logics approach (Thornton et al., 2012), which we use to theorize how competing institutional logics and cultural frames of the traditional work environment and HRM approaches can affect how organizations manage the issue of the work environment. The purpose of our paper is therefore to use an institutional logics framework to conceptualize developments in the management of work environment in the Nordic countries, and thereby show what logics are available to actors in the field, and finalize theorize on possible practical consequences for the work environment efforts in the Nordic organizations.

\section{Framework}

\section{Theoretical inspirations}

In a review of management of OHS (Zanko \& Dawson, 2012), the authors suggest that there is a lack of research on organizational implementation and, in particular, about how organizational actors make sense of external institutional demands for OHS. While the work environment research either has been focused on exposure and health risks on the individual level or on regulatory responses on a societal or at a sectoral level, the research on the organizational level has not produced a large body of work (Zanko \& Dawson, 2012). The call for more knowledge on how organizations implement and translate ideas, practices, and strategies to improve the work environment has been made by other scholars as well (Cox et al., 2010; Hasle et al., 2014; Nielsen et al., 2010).

To do just that Hasle et al. (2014) present a theoretical model of how work environment interventions function in organizational contexts. The authors use a framework partly inspired by the neo-institutionalism of DiMaggio and Powell (1983). In the paper, the authors ask, 'What makes organizations react to the application of policy instruments?' (Hasle et al., 2014), and while the use of neo-institutional analysis certainly is an innovation in the field of work environment research, we find that the model mentioned above relies too heavily on the idea of isomorphic pressures and thus could be further strengthened by incorporating some of the more recent theoretical developments in institutional theory, more specifically, the stream of theory that addresses the issues of institutional complexity and competing institutional logics (Berg Johansen \& Waldorff, 2015).

The neo-institutional perspective focuses on organizational isomorphism from coercive, normative, and mimetic pressures (DiMaggio \& Powell, 1983) in a top-down perspective (either through regulation or through a field's conception of legitimate choices) as the main driver behind organizational change. And, as scholars point out (Greenwood \& Suddaby, 2006; Seo \& Creed, 2002; Wooten \& Hoffman, 2008), the approach to institutional fields of the early new institutionalists such as DiMaggio \& Powell has significant shortcomings in explaining changes and emergence of new ideas and practices in organizational fields. W. Richard Scott describes how institutional change 'poses a problem for a lot of classical texts in institutional theory, most of which view institutions as the source of stability and order' (Scott in Greenwood \& Suddaby, 2006: 27). But, as our Introduction shows, the field of work environment management is not characterized by increasing homogeneity but actually just the opposite-an increasing diversity 
in organizational responses and strategies. Therefore, our proposal is to use the institutional logics perspective (Thornton et al., 2012)—an analytical framework based on the emerging 'change and complexity' theoretical perspective in institutional theory (Berg Johansen \& Waldorf, 2015: 5).

We use the institutional logics perspective to better understand work environment management as a field with multiple logics available to a wide array of actors vying for power and influence (Hoffman, 1999; Scott, 2014; Wooten \& Hoffman, 2008), and where different cultural frames and ideas coexist and make alternative strategies available to actors in the field (Scott, 2014; Waldorff, Reay et al., 2013).

The institutional logics perspective describes how organizations are presented with a wide array of different institutional logics containing different sources of legitimacy, identity, and organizational practices (Thornton et al., 2012). Whereas early institutionalism focuses on the processes of isomorphism and the conformity and uniformity that necessarily follow in organizational fields, institutional logics can help explain the differences that remain between related organizations and their practices and why organizational fields are changing and evolving.

The institutional logics perspective is, as mentioned above, a relative novelty when theorizing on organizational approaches to work environment management, but the analytical framework has been utilized in related research. Dyreborg (2011) used the framework to contribute to the explanations to understand shifts in the Danish regulatory framework of safety management in the construction industry. Bjørnstad and SteenJohnsen (2012) furthermore analyzed a workplace health promotion (WHP) scheme in a logistics company in Norway, using a similar concept of 'organizational logics'.

To provide an analytical framework with greater appreciation of the organizational contexts and how they are shaped, we reconceptualize the two approaches to the work environment, as two ideal types of field level institutional logics-one of compliance and one of commitment.

\section{Ideal types}

Ideal types are widely used tools in both sociology of work (e.g., Burawoy, 1985) and organization studies (e.g., Mintzberg, 1980), and are a methodological approach of distinction to create clarity in muddled empirical areas (Swedberg, 2005). Furthermore, as we describe later in our paper (in the section 'The Commitment Logic'), scholars of HRM have used idealtypes to categorize HRM practices into respectively 'hard' and 'soft' HRM practices (Legge, 2005). As ideal types, the two logics are not empirically detectable or concrete descriptions of any one organization's management philosophy, but are rather what Weber calls 'conceptual constructs' (Swedberg, 2005: 120) where certain properties, mechanisms, and practices of the field are amplified to better distinguish contradictions in overall strategies or organizational approaches (Swedberg, 2005). Ideal types are, as Max Weber himself writes: 'a harbor until one has learned to navigate safely in the vast sea of empirical facts' (Weber in Swedberg, 2005: 120), or as Scott puts it: 'useful maps to guide analysis and increase understanding of the real world' (Scott, 2014: 15). Therefore, the two ideal types cannot be seen as real phenomena that can be found and measured one to one, but rather as means to analyze 'cultural meanings into their logically pure components' (Whimster in Swedberg, 2005: 120). 
Therefore, it is also important to note that in reality, the logics developed in our paper will not be two obviously distinctive systems of meanings and practices always recognizable in organizations, but on the other hand, they will blend and mix in various competitive and cooperative constellations as we elaborate in the following section.

The two logics in the present paper are constructed from multiple different theoretical and empirical sources to illustrate these cultural meanings. The sources are chosen by the authors and used in the formulation of the two ideal types. This rather eclectic selection of sources should not be seen as an empirical proof of our model, but rather as illustrations of our points about the two emerging field-level logics. Our theoretical sources are mainly drawn from Anglo-American scholarly traditions, which in one way or another have had an impact on the management ideas in Scandinavia. Our empirical illustrations are all from Nordic labour market contexts.

Not to simply name them the HRM logic, the OHS logic, or the work environment logic is an analytical choice we make for a number of reasons. First, because HRM, OHS, and work environment are concepts with a multitude of meanings and definitions, and as mentioned above, we believe that these names alone would obfuscate our essential points. Second, we want to make it clear that the commitment logic in our view is not practiced solely in HR departments, while the compliance logic in a similar vein is contained not only within OHS management units. Third, institutional logics are not the same as an ideology or a management theory (Thornton et al., 2012). Institutional logics are the overall framework of identities, ideas, and practices (which also includes ideologies or management theories). Thus, we identify a set of ideas and practices, which ultimately revolves around the principle of creating committed and motivated employees - the commitment logic, and a set of ideas and practices that revolves around the goal of complying with external demands to maintain legitimacy and legality-the compliance logic.

The two ideal types illustrate the wide array of strategies, practices, frames, and norms that are available to actors in the field of OHS management. We will, after a presentation of the basic concepts in institutional logics, get back to the analysis of the two ideal types, describing the norms, beliefs, and practices that make up the organizational contexts where the two typologies are enacted, and thus show how OHS practices are culturally embedded, and thereby at the same time leaving space for agency of the actors involved in the work environment management.

\section{Institutional Logics}

The institutional logics framework is developed over the last two decades and seeks to explain how 'individual and organizational actors are influenced by their situation in multiple social locations in an inter-institutional system' (Thornton et al., 2012: 2).

\section{Institutional Orders (Macro-level)}

Institutional logics is an attempt to understand and reconcile structure and agency in organizational sociology (Thornton et al., 2012), while at the same time it attempts to provide a framework to analyze and understand the behavior of real-world organizations 
and organizational actors-a level of analysis that has been somewhat forgotten in the mainstream of institutional theory in the last decades (Berg Johansen \& Waldorff, 2015; Greenwood et al., 2014). The main and most simple point is that all institutions and societal actors are connected in a network of 'institutional orders' (Thornton et al., 2012), and that these can be found in instantiations at the various levels in society where they are shaped and refined into collective identities and thus provide actors with categories, organizing principles, and frames (Thornton et al., 2012). Researchers have used these broad principles of institutional logics as inspiration for analyses in various institutional and organizational settings, from the strategizing of book publishing companies (Thornton \& Ocasio, 1999) over the symbolic struggles between modernizers and reactionaries in French cuisine (Rao et al., 2003), to competing logics in software development (Westenholz, 2012).

The inter-institutional system consists of seven overall ideal type orders: family, religion, state, market, profession, corporation, and community. Each of the orders consists of values, modes of governance, legitimacy, and authority (Thornton et al., 2012: 73). So, the orders in the inter-institutional system each build what can be described as 'core societal institutions' on the macro-level and the values, rules, and practices they contain (Greenwood et al., 2014: 1214). And while each of these orders are distinct systems with distinct rules, values, and practices, they will, on a meso-level of organizational fields, appear as the institutional logic specific for the particular field. The main argument in the institutional logics perspective is that a specific empirical context always refers back to one or more of the institutional orders on a macro level in society. In this way, a meso-level institutional logic in the field of work environment that places trust in systems, bureaucracy, and compliance can be seen as an instantiation of the macro-level order of the state, and another logic that values organizational performance and commitment to the values and culture of the organization can be seen as an instantiation of the corporate order.

\section{Institutional Logics in Organizational Fields (Meso-level)}

The organizational field is the meso-level social arena between the overall level of society, and the individual organization and organizational actors. It consists of groups of organizations and actors who share some common characteristics or issues. It is at this level in the institutional logics perspective, where the overall institutional orders of the state and the corporation are transformed into specific instantiations of logics work environment management. DiMaggio and Powell (1983) originally defined organizational fields in their seminal paper as groupings of organizations with commonalities in terms of products, customers, or suppliers.

Hoffmann (1999) and others later revised this conception of fields. He describes how fields can be organized around an issue (in his case, environmental management in the American chemical industry). In this way, the field becomes the arena of power struggles between actors with divergent interests, as well as an arena that presents competing institutional logics to organizations. So, whereas organizational fields were mainly seen as the medium for institutional isomorphism in organizations (Seo \& Creed, 2002; Wooten \& Hoffman, 2008), we see them as arenas not only causing organizations to change their practices and identities through institutionalization but also as arenas 
that are themselves subject to change processes and conflicts as well (Hoffmann, 1999; Wooten \& Hoffman, 2008).

\section{Institutional Logics in Organizations (Micro-level)}

Field-level logics are bridging the societal-level orders and their logics with the actions and practices of organizations and individuals in society. Field logics are both shaped by the institutional orders on a societal-level at the same time, as they are shaped by processes happening in-field (Thornton et al., 2012:148). Even formerly stable fields are subject to change given the right circumstances. So, where the organizational field can act as a medium for the institutionalization and further diffusion of already established institutional logics, it can also see the rise of new and alternative logics that challenge the current orthodoxies (Greenwood \& Suddaby, 2006; Seo \& Creed, 2002) or, in some cases, coexist with the former (Goodrick \& Reay, 2011; Waldorff et al., 2013). Researchers point out that institutional logics can exist in various constellations (Goodrick \& Reay, 2011)-both competitively, that is, competing for dominance in the given field or organization, in a segmented form where the competing logics exist side by side in separate spheres of the organizational life, or even in cooperative form where the existence of multiple institutional logcs can actually enhance and empower each other and the practices they entail (see Goodrick \& Reay, 2011, or Lindberg, 2014; Waldorf et al., 2013).

\section{Institutional Logics of Work Environment Management}

The key constructs for the logic of our two typologies for work environment management, compliance and commitment, are outlined in Table 1.

Table I Institutional logics of work environment management

\begin{tabular}{|c|c|c|}
\hline & Compliance & Commitment \\
\hline Institutional orders & $\begin{array}{l}\text { - State } \\
\text { - Corporation }\end{array}$ & - Corporation \\
\hline Key historical events & $\begin{array}{l}\text { - Command-control regulation } \\
\text { - 'Safety first' movement } \\
\text { - Risk assessment and reflexivity }\end{array}$ & $\begin{array}{l}\text { - The Hawthorne studies } \\
\text { - Socio-technical experiments } \\
\text { - Increasing environmental complexity } \\
\text { - Increasing competition }\end{array}$ \\
\hline Foundational theories & $\begin{array}{l}\text { - 'Rational systems' approach } \\
\text { - Scientific management } \\
\text { - Safety management } \\
\text { - Occupational health and safety } \\
\text { management systems }\end{array}$ & $\begin{array}{l}\text { - 'Natural systems' approach } \\
\text { - Human resource theory } \\
\text { - Elton Mayo's therapeutic management } \\
\text { - McGregor's TheoryY }\end{array}$ \\
\hline
\end{tabular}

In the following part, we present the two logics, their relation to the inter-institutional orders, historical development and their roots in various management and organization theories and perspectives. 


\section{The Compliance Logic}

In the earliest days of management of health and safety in organizations, two diverging tendencies emerged. A regulatory strand that promoted and developed governmental control and legislation emerged especially in Germany and England, also known as the command-control model, while an American 'safety management' strand chose the path of self-regulation, where businesses themselves work to combat accidents and promote safety (Abrahamsson \& Johansson, 2013). The compliance logic is in many ways an amalgam of these two strands that together became the foundation of the compliance logic's combined understanding of both the work environment, and the management and regulation thereof (Abrahamsson \& Johansson, 2013).

The regulatory strand has been characterized by a move from what can be described as 'command-and-control' systems to a more reflexive paradigm of OHS-management (Aalders \& Wilthagen, 1997). From the 1970s and onward, it became increasingly evident that the command-and-control systems were not adequate to tackle the ever more complex health and safety problems, and the need for a move toward more reflexivity and self-regulation on a workplace level became evident (Hasle, 2010). A number of Western countries subsequently implemented new regimes of OHS legislation that were characterized by three common denominators (Frick \& Wren, 2000: 22):

- Employers responsibility for OHS on a workplace level,

- Comprehensive and separate OHS-legislation,

- Workers involvement in OHS-management.

The last point especially was the result of the political strength of both trade unions and their political counterparts in center-left governments during the last half of the $20^{\text {th }}$ century, and can be seen as a prime example of the way that the industrial relations of this era tried to institutionalize systems of consent between employees and employers while at the same time acknowledging the basic conflict of interest between the two parties-the so-called 'conflict-based consensus' approach (Jensen, 2012). Johnny Dyreborg describes this development in the following way: 'The command and control governance model was in this way supplemented by a decentralized participation model' (Dyreborg, 2011:142). In his institutional history of the Danish work environment, this participatory logic in turn again is supplemented by another logic, which he dubs the 'market logic' (Dyreborg, 2011).

In the management strand, on the other hand, the first programs to secure healthy and safe workplaces were rooted in the 'safety first' movement of the early $20^{\text {th }}$ century (Nielsen, 2000), and eventually saw large corporations maintaining systematic registration of accidents and extensive strategies for risk prevention. This evolved further into more systematic approaches in large organizations, such as the Dupont STOP approach (Safety Training Observation Program), which emphasized behavioral regulation of employees to maintain safe procedures and to report any unnoticed risks or hazards. The STOP approach is still in place in large organizations across the globe but is, to a large extent, developed into systems of OHS management (Frick \& Kempa, 2011; Hohnen \& Hasle, 2011).

Safety management and the regulatory strand have in many ways merged with the introduction of the so-called 'occupational health and safety management systems', 
which have become mandatory in various forms (Frick \& Kempa, 2011). The 1989 Framework Directive (89/391/EEC) of the European Union is a good example of regulatory demand for an OHS-management-like mandatory system. OHS management systems ideally lead to implementation and maintenance of systematic managerial approaches to the work environment (Kaj Frick \& Kempa, 2011; Hohnen \& Hasle, 2011; Robson et al., 2007). But from command-control, through the legislative regulation of the 1980s, and finally in the systematic approaches of OHS management from the 1980s and onward, the main logic has been that of risk management. This is apparent in the framework directive from the European Union (Frick, 2011), in national legislations (Walters \& Wadsworth, 2014), and the international standards and certificates on OHS on which voluntary OHS management systems are based (Hasle \& Zwetsloot, 2011; Hohnen \& Hasle, 2011; Kaj Frick \& Kempa, 2011).

\section{Institutional orders}

The compliance logic is both based on the order of the state and the order of the corporation. It adheres to the corporate bureaucracy and the hierarchies embedded in this. Furthermore, the logic also has the purpose protecting the corporation from liability, from costs associated with accidents and health issues, and thus maintaining the market position of the organization. Through the years however, the main counterpart of the compliance logic has been the legal requirements and authorities with which organizations should comply-the intention of the internal compliance systems (OHS management system) is to mimic the external regulatory goals (Parker \& Gilad, 2011).

\section{Theoretical foundations}

The theoretical inspirations of the compliance logic all see organizations as rational systems, a view that organizations consist of 'purposeful and coordinated agents' (Scott \& Davis, 2007: 36). Therefore, goal specificity and a high degree of formalization characterize the logic, as well as the belief in systematization and thorough analysis and descriptions of all steps in all processes.

An important point of departure for the compliance logic is Taylor's scientific management (Frick \& Wren, 2000: 21). The Taylorist legacy is, in terms of the compliance logic and the work environment, especially evident in the idea that knowledge and processes can be understood, rationalized, and reduced into general management systems and manuals.

The overall principles of scientific management were made specific to health and safety by Heinrich and Petersen (Heinrich et al., 1980; Nielsen, 2000). Their principles of safety illustrate the rational approach: (1) Unsafe acts, conditions, or accidents are all symptoms of failures of management and the system, (2) events and conditions that produce injuries can be predicted, identified, and thus controlled, (3) safety is a function like any other organizational function. It should be dealt with as such (like quality, production, or sales), (4) safety is achieved through fixed procedures of accountability for line management, (5) the responsibility of the specialized function of safety should deal with work environment issues by defining root causes of accidents and by maintaining the management system (as described by Nielsen, 2000:106). 


\section{The Commitment Logic}

Modern HRM has two different main objectives in organizations-one transactional and the other transformational (Boglind et al., 2011; Storey et al., 2009). The former ensures that all employee-related administration is managed competently. This objective covers employment relations, legal issues, salary, union negotiations, and hiring and firing practices, to name a few. The latter, on the other hand, is concerned with change management and 'long-term strategic' work (Storey et al., 2009). It may include developing competencies, utilizing hidden human resources strategically, and developing the human capital and dynamic capabilities inside the companies. The commitment logic presented in this paper can be seen as a part of the transformational version, which in turn is partly rooted in the theories of cooperation and management developed by the human relations school.

The human relations school of management philosophy is an important theoretical inspiration to the transformational version of HRM and, therefore and by extension, also for the commitment logic. One of the most famous organizational studies is also the foundational description of the human relations school: The Hawthorne Studies that were initiated in 1927 by Elton Mayo and his team of researchers at the Hawthorne Plant of the Western Electric Company (Shafritz \& Ott, 2001). Without retelling this story again (see Roethlisberger, 2001), these studies directed management theorists interest toward motivation as covering other aspects than the one provided by a salary. Variables included among others personal needs, managerial feedback, and group norms (Shafritz \& Ott, 2001:146). Furthermore, Mayo's own writings (2003) emphasized that good management requires understanding of the human conditions and problems that workers face to further understand the social and psychological aspects of work in order to improve productivity. Mayo and later human relations scholars' thoughts on the nature of the employment relationship, and the employees on the receiving end of these relationships, are core concepts and practices of the soft version of HRM and thus in the commitment logic (see O'Connor, 1999, for a contemporary and thororugh analysis of Mayo's philosophy).

Human relations theories and thoughts were mainly transformed into HRM in an Anglophone context and then later brought across the Atlantic to mainland Europe (Brewster, 2007). Another bundle of theories and practices inspired by the human relations paradigm came from the researchers at the Tavistock Institute and are known as the socio-technical systems approach (see Trist \& Bamforth, 1951). They played an integral part in the development of the particular Nordic working life approach to organizational development (Hasle \& Sørensen, 2013). More specifically, the human relations inspired concepts constituted the main inspiration behind the Nordic approach to working life and organizational development (Thorsrud \& Emery, 1970). The ideas and aspirations of the Nordic approach were critical of Tayloristic workplace designs and emphasize 'workers' psychological needs that work should fulfill' (Hasle \& Sørensen, 2013). These are needs that exceed basics such as economic security, just treatment, and time to rest, but include subjects such as autonomy, participation, and recognition as well (Hasle \& Sørensen, 2013).

HRM can be seen as an answer to increasing organizational and environmental complexity. Scholars agree that the growth of HRM in the last 30 years is partly due to the macroeconomic shift from industrial production to the knowledge economy, and

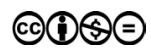


partly due to the increasing complexity of both communication and manufacturing processes (Holt Larsen, 2009; Legge, 2005). Increasing competition in the global marketplace, challenges of new and better production systems from, among others, Japan, created a demand for dynamic and flexible production systems that required organizations to start managing the employee relationship strategically and with competitive advantages in sight. In this business environment, a great variety of HRM-practices such as strategic recruitment, employee competency development, and motivational tools were developed and adopted. An early distinction in different HRM approaches was made between the 'soft' commitment-based and 'hard' models based on performance, constant measurement, and a liberal use of hiring and firing to suit the strategic needs of the day. The soft were described as 'developmental-humanist' (Legge, 2005) and seek to increase performance through commitment, well-being, and motivation. This model was later implemented and further developed in, for instance, 'high commitment management' and the AMO model of modern HRM (Ability, Motivation, and Opportunity) (Guest, 2011).

\section{Institutional orders}

The logic is rooted in HRM that in turn views the organization through a managerialist lens of the organization, with respect to legitimacy and authority. In both the aforementioned transactional and the transformational aims, the corporate logic shines through. The transactional practices develop and maintain the inner workings of corporate bureaucracy and hierarchy through rewards and sanctions, while the transformational practices have the increased market position and the utilization of the human resources to achieve it, as a raison d'etre.

The question that we can ask on the commitment strategy of modern HRM is 'commitment to what?' (Legge, 2005: 209). In an economic and societal climate of fluidity, flexibility, and change, highly skilled employees do not necessarily feel a strong connection to one specific organization. Storey et al. (2009) point to this as an important reason for the commitment strategy of HRM. It is necessary to create a sense of community and commitment, because a priori commitment and solidarity of the late modernity tend to focus on groups outside the specific organization (professional associations, trade unions, educational background, etc.). So, reciprocal trust-filled relations and organizational culture become tools to create commitment and motivation.

\section{Foundational theories}

The foundational theories of the commitment logic all fall into the natural systems category as opposed to the rational systems view of the compliance logic (Scott \& Davis, 2007). So, where the latter primarily sees goal specificity and formalization as the features distinguishing organizations from other kinds of social systems, the natural systems understanding, while acknowledging these two features as existing in organizations, argues that goal complexity and informal structures exist as they do in all social systems, and that these have greater significance in organizational 
development (Scott \& Davis, 2007: 60). This is especially apparent in two ways in the logic of commitment. Actors will not only pursue organizational output goals directly as fully rational agents (e.g., increased financial or organizational performance of the organization, more effective use of resources, etc.) instead, organizational actors pursue other less rational goals (social recognition, reward, satisfaction, self-actualization, etc.), which will divert our attention, energy, and resources from these rational goals. Organizations therefore have to align 'maintenance goals' to the output goals (Scott \& Davis, 2007, p. 60). Furthermore, informal structures exist (collectivities) and often times guide organizational actors' choices as much as formalized structures and systems.

The HRM perspective is a significant theoretical inspiration for the commitment logic. Human resource theory (or, perhaps more accurately, bundle of theories) rests upon the assumption 'that organizational creativity, flexibility, and prosperity flow naturally from employee growth and development' (Shafritz \& Ott, 2001: 145), and, more importantly that the people are the most important asset of any organization (Shafritz $\&$ Ott, 2001). From early descriptions (see Beer et al., 2015), HRM was characterized first and foremost by a strategic approach to people-management. That is, employees are resources to be used strategically, as well as resources that should be recruited, evaluated, rewarded, and sanctioned based on their strategic merits (Storey et al., 2009). Furthermore, another common denominator for most HRM models was that it should be both transactional and transformational at the same time, meaning that HRM manages both administrative tasks such as salary, bonus systems, and legal requirements in hiring and firing and so forth, while at the same time developing and transforming the human resources to improve performance, motivation, and corporate culture (Storey et al., 2009; Ulrich et al., 1995).

Elton Mayo's rejection of the homo economicus approach to employees (as seen in Taylor's writings) is another foundational theory of the commitment logic. In Mayo's theories, man was not simply reacting to incentives or sanctions, but reacting because of deeper emotional traumas and instabilities (Bruce \& Nyland, 2011; O'Connor, 1999; Schneider, 1999). Furthermore, employees were seen as irrational and in need of empathy, love, and understanding from the managers. The lack of these was the real reason behind industrial unrest (Bruce \& Nyland, 2011; O'Connor, 1999). Mayo's prescription for industrial captains of his time was that all administrators should be skilled listeners who could understand the social and emotional needs of their employees (Mayo, 2003).

A third theoretical inspiration comes from McGregor (2001) and his Theory Y. He advanced the points of Mayo in his Theory $\mathrm{Y}$ where he claims that (1) employees (in their harmonious state) do not have an inherent dislike for labor, (2) that punishment and control are not as effective motivators as rewards, and (3) that a reward that 'satisfies the ego and self-actualization needs' is more effective than an economic reward (cited from Scott \& Davis, 2007: 67). McGregor furthermore described principles of management that are all foundational behind the commitment logic. Management is responsible for the organization of a productive enterprise. They cannot conjure motivation and potential in people; these are inherent properties of human nature. Management, however, has to provide people with the right opportunities to discover the motivation and potential by providing the right kind of 'organizational conditions and methods of operation' (McGregor, 2001: 183).

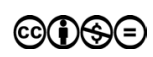




\section{Possible consequence for work environment management}

The two institutional logics in the field of the work environment not only differ in terms of theoretical roots, history, and foundational assumptions, but they may also have consequences for concrete environment practices in Nordic labor markets and inside organizations. Abrahamsson and Johansson (2013) sum up the development of the work environment field in Scandinavia during the last 50 years in the following way:

The path of development has gone from noise reduction to coaching and from viewing the work environment as an area for problems to viewing it as an area for workplace learning and for strategic development from management. (p. 7)

It is this development that we suggest to utilize as the analytical lens of institutional logics. To be more specific, we have identified three key areas where the two logics differ remarkably and that can therefore help illuminate how they present different organizational practices to organizations and actors in the field.

Table II The institutional logics and their approaches to work environment management

\begin{tabular}{|c|c|c|}
\hline $\begin{array}{l}\text { Approaches to work } \\
\text { environment management }\end{array}$ & Compliance logic & Commitment logic \\
\hline Motivation behind efforts & - Economic and social compliance & $\begin{array}{l}\text { - Work environment leads to job } \\
\text { satisfaction that in turn leads to } \\
\text { higher productivity }\end{array}$ \\
\hline Primary agents of change & $\begin{array}{l}\text { - Experts and specialists (external } \\
\text { or internal) }\end{array}$ & - Management (line or staff) \\
\hline Work environment strategies & $\begin{array}{l}\text { - Risk prevention through } \\
\text { systematization of processes } \\
\text { at the organizational level }\end{array}$ & $\begin{array}{l}\text { Development of competencies } \\
\text { and resilience at the individual } \\
\text { level }\end{array}$ \\
\hline
\end{tabular}

\section{Motivation behind work environment efforts}

As the name of the two logics suggests, they differ fundamentally when it comes to the organizational motivation behind the work environment efforts. The most basic approach to work environment management in the compliance logic is just that-compliance with rules: rules that can take the form of both laws and of certified standards, which are becoming increasingly prevalent in the management of the work environment (Hohnen \& Hasle, 2011). Motivation for this compliance takes two forms. What Nielsen and Parker (2012, p. 431) term 'economic motivation' for compliance. Here, the aim is to ensure that the work environment efforts are saving the organization money on fines from external regulators, sickness absence, and from the payment of damages to injured employees. Furthermore, we can point to social motives for compliance (Nielsen \& Parker, 2012). In this form, work environment efforts are developed to maintain legitimacy and respect from competitors, customers, and regulators and can be viewed as a form of institutional isomorphism (Hasle et al., 2014). Motivation in the compliance logic can be summarized like this: 


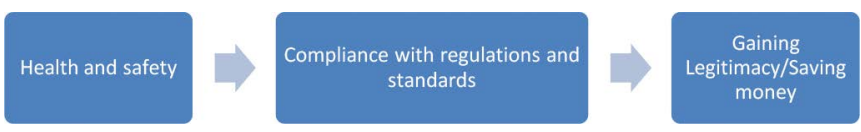

The approach of the commitment logic, on the other hand, is that well-being and job satisfaction lead to commitment that again increases organizational performance. This is the most fundamental approach that the commitment logic makes available to actors in the field of work environment management. The approach can roughly be summarized in the following formula:

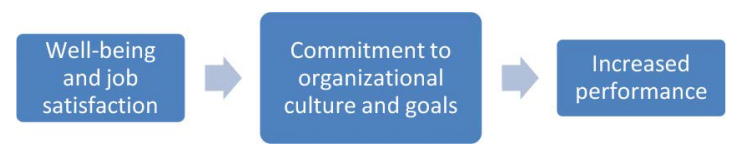

In the end, this performance lens is the key behind the commitment logic's approach to the work environment. Initiatives and practices toward the work environment and wellbeing will necessarily be evaluated through a performance lens-are they motivating people? This could in turn mean that aspects of the work environment without a clear performance link are overlooked by work environment actors in the organization, for example, long-term exposure to chemical substances that can cause cancer.

\section{Work environment strategies-collective risk prevention or individual resilience building?}

A second area in which the two logics' prescribed approaches will differ has to do with which actual work environment practices to implement in the organizations. If one concept should encompass the compliance logic, it would be 'safety from risk' (Hohnen $\&$ Granerud, 2010). The scope and focus of the approaches to safety and health have expanded and changed through the years, as has the knowledge of risks and hazards, but the main battle cry of risk prevention has endured. Therefore, the compliance logic generally prescribes efforts on an organizational and thus collective level. Because of the focus on risks and hazards, and because of the belief in causal predictions and preventions in terms of what leads to accidents and injuries, a characteristic of the compliance logic is the overall systematic and rational approach to health and safety: the belief that accidents, injuries, or sicknesses are mainly to be considered failures in said system. This also appears in the required reflexivity of contemporary OHS management systems. Because of increasing complexity, the multi-causality of work environment issues and the idiosyncratic nature of modern organizational contexts, the need is to make them comply with procedural regulations (e.g., mandatory risk assessment, internal and external audits, reporting, running supervising processes from the top management) (Frick \& Kempa, 2011; Rocha \& Hohnen, 2010).

When organizational actors employ compliance approaches such as the use of certification from international standards, or simply work toward avoiding actions from the regulatory agency, research shows that they will give attention to work environment issues that can be made auditable, that is to say made into 'manageable procedures and 
auditable performances' (Hohnen \& Hasle, 2011) such as checklists and safety KPIs and thus fitting the basic rational understanding of the risk management approach. This will also, in most cases, give priority to aspects such as safety risks and physical exposures that can be measured and registered, over complex and possibly hidden psychosocial work environment issues (Jespersen et al., 2016).

The commitment logic, on the other hand, is rooted in the therapeutic management ideas of human relations theorists and in the view that all individuals have varying needs and sentiments. In this light, work environment problems are dealt with at the level of the individual. Some commitment-inspired work environment strategies are somewhat reactive in nature and are mainly in place to mitigate the strains that the organizational demands can put on the working life of the individual employees. One example here is work-life balance initiatives such as the possibility for flexible work arrangements in terms of both temporal and spatial flexibility and good conditions for paternity and maternity leave (Håpnes \& Rasmussen, 2011; Hyman \& Summers, 2007; Jacobsen et al., 2013). Another example is employee assistance programs that provide employees with free access to skilled health professionals such as physiotherapists, psychologists, masseurs, and chiropractors.

Other commitment strategies focus on the optimization of the individual employees through the development of resilience to strains and stresses from a high performance work environment. We can see these strategies of resilience in WHP schemes (WHP), which focus on improving the physical health of the employees (Bjørnstad \& SteenJohnsen, 2012; Kamp, 2009; Larsson et al., 2015), in training and fitness excersises to combat muscular-sceletal strains (Sundstrup et al., 2016), in individual stress management training to improve coping skills of the employees (Nytrø et al., 2000), and finally in the concept of 'employee development dialogues' (Triantafillou, 2003) and 'performance appraisal interviews' (Asmuss, 2013), which seek to develop competencies and strengthen the fit between individual competencies and the demands of the job.

\section{Primary actors in work environment management}

The trust in systems and formalized structures of the compliance logic is rooted in the rational systems assumption. Events, accidents, and root causes for ailments, and-more importantly-the systems that can prevent them, can be measured and mapped out in a scientifically correct manner by experts and engineers. Thus, employees and line management are the receivers of the expert knowledge and maybe somewhat responsible for maintenance and supervision of the control systems, but the main solutions and designs of the work environment management fall mainly on either staff specialists inside the organizations (Seim et al., 2016) or by external consultants (Limborg, 2001).

The commitment logic, on the other hand will, as shown above, tend to see the work environment as just another managerial task, carried out either through direct line management or possibly with support from a staff specialist. An example can be found in the study by Knudsen et al. (2011) wherein the authors show that workplaces that employ management techniques from what we have dubbed the commitment logic prioritize the work environment and well-being of the employees. These workplaces employ more direct participatory models for employee-management relations. This approach reflects human relations inspired ideas about empathetic and semi-therapeutic 
roles for management. Roles that require training in well-being issues should be on the agenda for top and especially for line managers in every successful organization because they will act as the main facilitators of social cohesion and community in the workplace.

\section{Perspectives}

In this article, we have analyzed how the institutional field of the work environment in the Nordic countries in recent decades has been influenced by management approaches from HRM and how the field is thus composed of multiple and somewhat diverging approaches to the management of the work environment issues. To understand these field changes, we have constructed a typology of two institutional logics of compliance and commitment, respectively, and shown how they differ in terms of theoretical foundations, normative aspirations, and practical approaches to work environment issues.

The logics that we mapped out in this paper are ideal types, not detailed descriptions of the empirical reality. Therefore, the concrete organizational practices change from context to context and the two logics is can both interact as a competitive constellation, but just as well can interact in a complementary and thus cooperative constellation. The ideal types of commitment and compliance can help to underline which understandings and preconditions OHS actors in organizations draw upon when they translate policy, regulations, voluntary strategies, or collective bargaining agreements into concrete organizational practice and strategies.

A number of different organizational approaches can be imagined based on the two ideal types. Few approaches will lean entirely one way or the other and thus represent either a commitment-based or a compliance-based approach. In these instances, organizational strategies and practices will come close to the clear idealtypical practices of the logic of compliance and commitment, respectively, that we have outlined in the previous paragraphs. A more likely variant would be a model of constellations of logics. We can imagine an organization with a strong HR department with a commitment-based overall strategy to the work environment, but at the same time employing actors to make sure that the organization complies with basic regulations standards. In this model, the overall work environment approach and strategy mirror the commitment-based logic, but with specific compliance-based practices in place. Again, another model would be a segmented model where the two logics coexist in the organization, but in different functions and with separated responsibilities. Examples of this model would include organizations that have, on the one hand, a compliance-based department with its focus on safety, accidents, and the chemical and physical work environment and, on the other hand, a commitment-based department with its focus on well-being, psychosocial factors, and health development. Two different variants could be imagined: one of peaceful coexistence and clear demarcation of responsibilities between the two functions, and one of contestation and competition over resources and jurisdiction. The logics of compliance and commitment are thus not inherently competing or coexisting, but can interact in various constellations both competitive and cooperative based on the organizational context in which they exist.

In other words, fields do not consist of overly determining organizational ideas that actors then mindlessly carry into their organizations and start to enact (Binder, 2007). Organizational actors are real people with feelings, histories, political views, and ethical

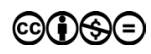


rules for themselves. Likewise, organizations are entities with their own history, idiosyncrasies, and social systems. As Binder (2007) writes:

'They [organizations] are places where people and groups (agentic actors, not "institutional dopes") make sense of and interpret, institutional "vocabularies of motive" (Fligstein, 1997), and act on those interpretations'. (p. 551)

In other words, actors do not act on the prescriptions of institutional logics of the field alone, but rather on the shared interpretations of these that arise from social interactions on an organizational level. Therefore, further studies are also necessary to investigate concrete empirical settings where the competing institutional logics of the field are enacted and shaped into concrete work environment practices.

As we have made apparent earlier in this paper, there is a need for research on the linkages between values and orders from a societal macro level, how they are embedded in the meso level of organizational fields, and finally the micro level processes inside the organizations, without either giving too much explanatory power to the structural impact of societal pressures or to unbound agents inside the organizations. As such, an institutional logic perspective can be the bridge between the various analytical levels, and our paper can hopefully act as a point of departure for further empirical studies of these and their connections. It is necessary to further investigate how institutional field logics of commitment and compliance are carried into the organizations, who carries them, and how are they interpreted into concrete work environment practices by actors when the rubber hits the road. Such knowledge can help to guide practitioners in the organization in such a way that they avoid the negative side effects of the compliance logic's too strong belief in a rational system that has difficulties in approaching, among others, psychosocial factors and the commitment logic's focus on the employees' individual responsibilities with a tendency to close the eyes on the employers' responsibility.

\section{References}

Aalders, M., \& Wilthagen, T. (1997). Moving Beyond Command-and-Control: Reflexivity in the Regulation of Occupational Safety and Health and the Environment. Law \& Policy, 19(4), 415-443. doi: http://dx.doi.org/10.1111/1467-9930.t01-1-00034.

Abrahamsson, L., \& Johansson, J. (2013, January 1). One Hundred Years of Inertia: An Exposé of the Concept of the Psychosocial Work Environment in Swedish Policy and Research. Nordic Journal of Working Life Studies. doi: http://dx.doi.org/10.19154/njwls. v3i1.2518.

Asmuss, B. (2013). The emergence of symmetries and asymmetries in performance appraisal interviews: An interactional perspective. Economic and Industrial Democracy, 34(3), 553-570. doi: http://dx.doi.org/10.1177/0143831x13489045.

Beer, M., Boselie, P., \& Brewster, C. (2015). Back to the Future: Implications for the Field of HRM of the Multistakeholder Perspective Proposed 30 Years Ago. Human Resource Management, 54(3), 427-438. doi: http://dx.doi.org/10.1002/hrm.21726.

Beer, M., Spector, B., Lawrence, P., Mills, D., \& Walton, R. (1984). Managing human assets. Berg Johansen, C., \& Waldorff, S. B. (2015). What are Institutional Logics - and Where is the Perspective Taking Us? Academy of Management Proceedings, 2015(1), 14380-14380. doi: http://dx.doi.org/10.5465/ambpp.2015.14380abstract. 
Binder, A. (2007). For love and money: Organizations' creative responses to multiple environmental logics. Theory and Society, 36(6), 547-571. doi: http://dx.doi.org/10.1007/ s11186-007-9045-x.

Bjørnstad, T. C., \& Steen-Johnsen, K. (2012, June 1). Beyond Planning: The Implementation of a Worksite Health Promotional Scheme. Nordic Journal of Working Life Studies. doi: http://dx.doi.org/10.19154/njwls.v2i2.2357.

Boglind, A., Hällstén, F. \& Thilander, P., 2011. HR transformation and shared services: Adoption and adaptation in Swedish organisations. Personnel Review, 40(5), pp. 570-588. doi: http://dx.doi.org/10.1108/00483481111154441.

Bratton, J., \& Gold, J. (2012). Human Resource Management: Theory and Practice (5th ed.). Palgrave Macmillan.

Brewster, C. (2007). A European perspective on HRM. European Journal of International Management, 1(3), 239-259. doi: http://dx.doi.org/10.1504/ejim.2007.014696.

Bruce, K., \& Nyland, C. (2011). Elton Mayo and the Deification of Human Relations. Organization Studies, 32(3), 383-405. doi: http://dx.doi.org/10.1177/0170840610397478.

Burawoy, M., 1985. The Politics of Production: Factory Regimes Under Capitalism and Socialism, Verso Books.

Cox, T., Taris, T. W., \& Nielsen, K. (2010). Organizational interventions: Issues and challenges. Work \& Stress, 24(3), 217-218. doi: http://dx.doi.org/10.1080/02678373.2010.519496.

DiMaggio, P., \& Powell, W. (1983). The Iron Cage Revisited: Institutional Isomorphism and Collective Rationality in Organizational Fields. American Sociological Review, 48(2), 147-160. doi: http://dx.doi.org/10.2307/2095101.

Dyreborg, J. (2011). 'Safety Matters Have Become Too Important for Management to Leave it Up to the Workers' -The Nordic OSH Model Between Implicit and Explicit Frameworks. Nordic Journal of Working Life Studies, 1(1), 135-160. doi: http://dx.doi.org/10.19154/ njwls.v1i1.2339.

Ehnert, I. (2009). Sustainable Human Resource Management - A conceptual and exploratory analysis from a paradox perspective. Heidelberg: Physica-Verlag. doi: http://dx.doi. org/10.1007/978-3-7908-2188-8.

Frick, K., \& Kempa, V. (2011). Occupational Health \& Safety Management System: When are They Good for Your Health? Brussels.

Frick, K., \& Wren, J. (2000). Reviewing occupational health and safety management: multiple roots, diverse perspectives and ambiguous outcomes. In K. Frick, M. Quinlan, P. L. Jensen, \& T. Wilthagen (Eds.), Systematic Occupational Health and Safety Management - Perspectives On An International Development (p. 527). Emerald Group Publishing Limited.

Friedland, R., \& Alford, R. R. (1991). Bringing society back in: Symbols, practices and institutional contradictions. In W. Powell \& P. DiMaggio (Eds.), The New Institutionalism In Organizational Analysis. University of Chicago Press.

Georg, S. (2014). Bæredygtige Organisationer [Sustainable Organizations]. In S. Vikkelsø \& P. Kjær (Eds.), Klassisk og Moderne Organisationsteori [Classical and Modern Organization Theory] (p. 704). København: Hans Reitzels Forlag.

Goodrick, E. \& Reay, T., 2011. Constellations of Institutional Logics: Changes in the Professional Work of Pharmacists. Work and Occupations, 38(3), pp.372-416. doi: http:// dx.doi.org/10.1177/0730888411406824.

Greenwood, R., Hinings, C. R., \& Whetten, D. (2014). Rethinking Institutions and Organizations. Journal of Management Studies, 51(7), 1206-1220. doi: http://dx.doi.org/10.1111/ joms.12070.

Greenwood, R., \& Suddaby, R. (2006). Institutional Entrepreneurship in Mature Fields: the Big Five Accounting Firms. Academy of Management Journal, 49(1), 27-48. doi: http:// dx.doi.org/10.5465/AMJ.2006.20785498. 
Guest, D. (2011). Human resource management and performance: still searching for some answers. Human Resource Management Journal, 21(1), 3-13. doi: http://dx.doi. org/10.1111/j.1748-8583.2010.00164.x.

Hart, S. M. (2009). Self-regulation, Corporate Social Responsibility, and the Business Case: Do they Work in Achieving Workplace Equality and Safety? Journal of Business Ethics, 92(4), 585-600. doi: http://dx.doi.org/10.1007/s10551-009-0174-1.

Hasle, P., 2010. Certificeret arbejdsmiljøledelse i et historisk perspektiv [Certified work environment management in a historical perspective]. In R. S. Rocha \& P. Hohnen, eds. Ledelse af Arbejdsmiljø - Certificering i praksis [Management of working environment - Certification in practice]. Nyt Teknisk Forlag, p. 165.

Hasle, P., Limborg, H. J., \& Nielsen, K. T. (2014). Working environment interventions Bridging the gap between policy instruments and practice. Safety Science, 68, 73-80. doi: http://dx.doi.org/10.1016/j.ssci.2014.02.014.

Hasle, P., Seim, R., \& Refslund, B. (2016). From employee representation to problemsolving - Mainstreaming OHS management. Economic and Industrial Democracy (Forthcoming).

Hasle, P., \& Sørensen, O. H. (2013). Employees as Individually and Collectively Acting Subjects-Key Contributions from Nordic Working Life Research. Nordic Journal of Working Life Studies, 3(3), 9. doi: http://dx.doi.org/10.19154/njwls.v3i3.3009.

Hasle, P., \& Zwetsloot, G. (2011). Editorial: Occupational Health and Safety Management Systems: Issues and challenges. Safety Science, 49(7), 961-963. doi: http://dx.doi. org/10.1016/j.ssci.2011.02.013.

Heinrich, H., Petersen, D. \& Roos, N., 1980. Industrial Accident Prevension: A Safety Management Approach, 5th ed. New York: McGraw- Hill, 1980.

Hoffman, A. J. (1999). Institutional Evolution and Change: Environmentalism and the U.S. Chemical Industry. The Academy of Management Journal, 42(4), 351-371. doi: http:// dx.doi.org/10.2307/257008.

Hohnen, P., \& Granerud, L. (2010). Forståelser af Arbejdsmiljø på Certificerede Virksomheder. In R. S. Rocha \& P. Hohnen (Eds.), Ledelse af Arbejdsmiljø - Certificering i praksis [Management of Working Environment - Certification in practice]. Nyt Teknisk Forlag.

Hohnen, P., \& Hasle, P. (2011). Making work environment auditable-A 'critical case' study of certified occupational health and safety management systems in Denmark. Safety Science, 49(7), 1022-1029. doi: http://dx.doi.org/10.1016/j.ssci.2010.12.005.

Holt Larsen, H. (2009). HRM: Ledelse af virksomhedens menneskelige ressourcer [HRM: Management of the human resources of the firm]. Ledelse Og Erhvervsøkonomi [Management and Business], (4), 7-19.

Holt Larsen, H. (2014). Human Resource Management. In S. Vikkelsø \& P. Kjær (Eds.), Klassisk og Moderne Organisationsteori [Classical and Modern Organization Theory] (pp. 589-612). København: Hans Reitzels Forlag.

Hyman, J., \& Summers, J. (2007). Work and life: Can employee representation influence balance? Employee Relations, 29(4), 367-384. doi: http://dx.doi.org/10.1108/ 01425450710759208.

Håpnes, T., \& Rasmussen, B. (2011). Policies and Practices of Family Friendliness. Time and Employment Relations in Knowledge Work. Nordic Journal of Working Life Studies, 1(2), 39-57. doi: http://dx.doi.org/10.19154/njwls.v1i2.2344.

Jacobsen, S., Bramming, P., Holt, H., \& Holt Larsen, H. (2013). Quality in Modern Nordic Working Life-Investigating Three Related Research Perspectives and Their Possible Cross-Fertilization. Nordic Journal of Working Life Studies, 3(3). doi: http://dx.doi. org/10.19154/njwls.v3i3.3011.

Jensen, C. S. (2012). Industrial Relations in Denmark: From Conflict-based Concensus to Consensus-based Conflict. Djøf Publishing. 
Jespersen, A. H., Hohnen, P., \& Hasle, P. (2016). Internal audits of psychosocial risks at workplaces with certified OHS management systems. Safety Science, 84, 201-209. doi: http://dx.doi.org/10.1016/j.ssci.2015.12.013.

Kamp, A. (2009). Bridging collective and individual approaches to occupational safety and health: what promises does workplace health promotion hold? Policy and Practice in Health and Safety, 18(1), 85-102. doi: http://dx.doi.org/10.1080/14774003.2009.116 $\underline{67730 .}$.

Kamp, A., \& Nielsen, K. T. (2013). Management of Occupational Health and Safety. In A. Sandberg (Ed.), Nordic lights: Work, management and welfare in Scandinavia. SNS Forlag.

Knudsen, H., Busck, O., \& Lind, J. (2011). Work environment quality: the role of workplace participation and democracy. Work, Employment \& Society, 25(3), 379-396. doi: http:// dx.doi.org/10.1177/0950017011407966.

Larsson, R., Stier, J., Åkerlind, I., \& Sandmark, H. (2015). Implementing Health-Promoting Leadership in Municipal Organizations: Managers' Experiences with a Leadership Program. Nordic Journal of Working Life Studies. doi: http://dx.doi.org/10.19154/njwls. v5i1.4767.

Legge, K. (2005). Human Resource Management: Rhetorics and Realities; Anniversary Edition. Palgrave Macmillan.

Limborg, H. J. (2001). The professional working environment consultant? A new actor in the health and safety arena. Human Factors and Ergonomics in Manufacturing, 11(2), 159-172. doi: http://dx.doi.org/10.1002/hfm.1006.

Lindberg, K., 2014. Performing multiple logics in practice. Scandinavian Journal of Management, 30(4), pp. 485-497. doi: http://dx.doi.org/10.1016/j.scaman.2013.12.007.

Mayo, E. (2003). The Human Problems Of An Industrial Civilization. In K. Thompson (Ed.), The Early Sociology of Management and Organization (p. 194). London \& New York: Routledge.

McGregor, D. M. (2001). The Human Side of Enterprise. In J. M. Shafritz \& J. S. Ott (Eds.), Classics of Organization Theory ( $5^{\text {th }}$ ed., pp. 179-184). Harcourt College Publishers.

Mintzberg, H., 1980. Structure in 5's: A Synthesis of the Research on Organization Design. Management science, 26(3), pp. 322-341.

Nielsen, K. T. (2000). Organization Theories Implicit in Various Approaches to OHS Management. In K. Frick, T. Wilthagen, M. Quinlan, \& P. Langaa Jensen (Eds.), Systematic Occupational Health and Safety Management - Perspectives On An International Development (p. 515). Emerald Group Publishing Limited.

Nielsen, K., Taris, T. W., \& Cox, T. (2010). The future of organizational interventions: Addressing the challenges of today's organizations. Work \& Stress, 24(3), 219-233. doi: http://dx.doi.org/10.1080/02678373.2010.519176.

Nielsen, V. L., \& Parker, C. (2012). Mixed Motives: Economic, Social, and Normative Motivations in Business Compliance. Law \& Policy, 34(4), 428-462. doi: http://dx.doi. org/10.1111/j.1467-9930.2012.00369.x.

Nytrø, K., Saksvik, P. Ø., Mikkelsen, A., Bohle, P., \& Quinlan, M. (2000). An appraisal of key factors in the implementation of occupational stress interventions. Work \& Stress, 14(3), 213-225. doi: http://dx.doi.org/10.1080/02678370010024749.

O'Connor, E. (1999). Minding the Workers: The Meaning of Human' and Human Relations' in Elton Mayo. Organization, 6(2), 223-243. doi: http://dx.doi.org/10.1177/ 135050849962004.

Parker, C., \& Gilad, S. (2011). Internal corporate compliance management systems: structure, culture and agency. In C. Parker \& V. L. Nielsen (Eds.), Explaining Compliance: Business responses to regulation (p. 386). Edward Elgar Publishing.

Pawlowska, Z., \& Eeckelaert, L. (2010). Mainstreaming OSH into business management. Bruxelles. European Agency for Safety and Health at Work. 
Rao, H., Monin, P., \& Durand, R. (2003). Institutional Change in Toque Ville: Nouvelle Cuisine as an Identity Movement in French Gastronomy. American Journal of Sociology, 108(4), 795-843. doi: http://dx.doi.org/10.1086/367917.

Robson, L. S., Clarke, J. A., Cullen, K., Bielecky, A., Severin, C., Bigelow, P. L., ... Mahood, Q. (2007). The effectiveness of occupational health and safety management system interventions: A systematic review. Safety Science, 45(3), 329-353. doi: http://dx.doi. org/10.1016/j.ssci.2006.07.003.

Rocha, R. S., \& Hohnen, P. (2010). Ledelse af arbejdsmiliø: certificering i praksis [Management of Working Environment - Certification in practice]. Nyt Teknisk Forlag.

Roethlisberger, F. J. (2001). The Hawthorne Experiment. In J. M. Shafritz \& J. S. Ott (Eds.), Classics of Organization Theory (5th ed., pp. 158-166). Harcourt College Publishers.

Schneider, S. C. (1999). Human and Inhuman Resource Management: Sense and Nonsense. Organization , 6 (2 ), 277-284. doi: http://dx.doi.org/10.1177/135050849962007.

Scott, W. R. (2014). Institutions and Organizations (4 ${ }^{\text {th }}$ ed.). SAGE Publications.

Scott, W. R., \& Davis, G. F. (2007). Organizations and organizing: Rational, natural, and open system perspectives ( $1^{\text {st }}$ ed.). Routledge.

Seim, R., Møller, N., \& Limborg, H. J. (2016). Professionelle og medarbejderrepræsentanter - nye roller i arbejdsmiljøarbejdet [Professionals and Employee Representatives - New roles in the working environment efforts]. Tidskrift for Arbejdsliv [Journal for Working Life], 18(1), 18-33.

Seo, M., \& Creed, W. (2002). Institutional contradictions, praxis, and institutional change: A dialectical perspective. Academy of Management Review, 27(2), 222-247. doi: http:// dx.doi.org/10.5465/amr.2002.6588004.

Shafritz, J. M., \& Ott, J. S. (2001). Classics of Organization Theory ( $5^{\text {th }}$ ed.). Harcourt College Publishers.

Storey, J., Ulrich, D., \& Wright, P. M. (2009). Introduction. In J. Storey, D. Ulrich, \& P. M. Wright (Eds.), The Routledge Companion to Strategic Human Resource Management (p. 528). Routledge.

Sundstrup, E., Jakobsen, M. D., Petersen, M. B., Jay, K., \& Andersen, L. L. (2016). Styrketrcening mindsker kroniske smerter og forebygger tab af arbejdsevne hos slagteriarbejdere [Training reduces chronical pain and prevents loss of fitness for work for slaughterhouse workers]. Copenhagen. National Research Centre for the Working Environment.

Swedberg, R. (2005). The Max Weber Dictionary: Key Words and Central Concepts. Stanford University Press.

Thornton, P. H., \& Ocasio, W. (1999). Institutional logics and the historical contingency of power in organizations: Executive succession in the higher education publishing industry, 1958-1990. American Journal of Sociology, 105(3), 801-843. doi: http://dx.doi. org/10.1086/210361.

Thornton, P. H., Ocasio, W., \& Lounsbury, M. (2012). The Institutional Logics Perspective A New Approach To Culture, Structure, And Process. Oxford: Oxford University Press.

Thorsrud, E. \& Emery, F.E., 1970. Industrial Democracy in Norway. Industrial relations, 9(2), pp. 187-196. doi: http://dx.doi.org/10.1111/j.1468-232X.1970.tb00505.x.

Torrington, D., Hall, L., \& Taylor, S. (2008). Human Resource Management. Financial Times Prentice Hall.

Trist, E. L., \& Bamforth, K. (1951). Some social and psychological consequences of the Longwall method. Human Relations, 4(3), 3-38. doi: http://dx.doi.org/10.1177/ 001872675100400101.

Tzafrir, S. S., Gur, A. B.-A., \& Blumen, O. (2015). Employee social environment (ESE) as a tool to decrease intention to leave. Scandinavian Journal of Management, 31(1), 136-146. doi: http://dx.doi.org/10.1016/j.scaman.2014.08.004. 
Ulrich, D., Brockbank, W., Yeung, A. K., \& Lake, D. G. (1995). Human resource competencies: An empirical assessment. Human Resource Management, 34(4), 473-495. doi: http://dx.doi.org/10.1002/hrm.3930340402.

Waldorff, S. B., Reay, T., \& Goodrick, E. (2013). A Tale of Two Countries: How Different Constellations of Logics Impact Action. In Institutional Logics in Action, Part A (Vol. 39 Part A, pp. 99-129). Emerald Group Publishing Limited. doi: http://dx.doi.org/10.1108/ S0733-558X(2013)0039AB008.

Walters, D., \& Wadsworth, E. (2014). Contexts and determinants of the management of occupational safety and health in European workplaces. Policy and Practice in Health and Safety, 12(2), 109-130. doi: http://dx.doi.org/10.1080/14774003.2014.11667806.

Westenholz, A. (2012). The Janus Face of Commercial Open Source Software Communities: An Investigation Into Institutional (non)work by Interacting Institutional Actors. Copenhagen Business School Press DK.

Wooten, M., \& Hoffman, A. (2008). Organizational fields: Past, present and future. In R. Greenwood, C. Oliver, K. Sahlin-Andersson, \& R. Suddaby (Eds.), The Sage Handbook of Organizational institutionalism. SAGE Publications.

Zanko, M., \& Dawson, P. (2012). Occupational health and safety management in organizations: a review. International Journal of Management Reviews, 14(3), 328-344. doi: http://dx.doi.org/10.1111/j.1468-2370.2011.00319.x. 